\title{
Identifikasi Kompetensi Pemrograman Komputer pada Lulusan Pendidikan Komputer untuk Pekerjaan Berkelanjutan
}

\author{
Torkis Nasution ${ }^{1 *}$ \\ ${ }^{1}$ Program Studi Teknik Informatika, STMIK Amik Riau \\ *e-mail: torkisnasution@stmik-amik-riau.ac.id
}

\begin{abstract}
Abstrak-Studi ini mengidentifikasi kompetensi pemrograman komputer yang diperlukan lulusan pendidikan komputer untuk pekerjaan berkelanjutan di Kota Pekanbaru, Provinsi Riau, Indonesia. Penelitian ini menggunakan desain penelitian survei deskriptif. Kuesioner terstruktur digunakan untuk pengumpulan data. Instrumen ini telah divalidasi oleh tiga ahli dalam pemrograman komputer. Cronbach Alpha statistik digunakan untuk menentukan konsistensi internal instrumen, menghasilkan kehandalan co-efisien 0,83. Mean dan standar deviasi digunakan untuk menjawab pertanyaan penelitian sementara ANOVA statistik digunakan untuk menguji hipotesis. Studi ini menemukan bahwa 25 kompetensi keterampilan, 18 kompetensi bisnis, dan 19 kompetensi sikap yang diperlukan oleh lulusan pendidikan komputer untuk pekerjaan berkelanjutan dalam pemrograman. Kompetensi ini diidentifikasi antara lain, kemampuan merangkai kode program, menguji dan debug dengan cepat dan efisien; mengeksplorasi dan mengevaluasi desain aplikasi, menganalisa kebutuhan dan spesifikasi kemudian desain, tes, dan mengembangkan perangkat lunak untuk memenuhi kebutuhan tersebut, merekomendasikan upgrade perangkat lunak untuk klien pengguna program yang ada dan sistem, kemahiran dalam data mining, kepercayaan diri tetapi terbuka untuk masukan, beradaptasi dengan perubahan sementara tetap fokus pada pekerjaan menjadi prioritas paling utama.
\end{abstract}

Kata Kunci : pemrograman komputer, keberlanjutan, pekerjaan, kompetensi, lulusan

\begin{abstract}
The study identifies the competencies necessary computer programming graduate computer education for sustainable employment in Kota Pekanbaru, Riau Province, Indonesia. The design of this study was a descriptive survey. Structured questionnaire was used for data collection. This instrument has been validated by three experts in computer programming. Cronbach Alpha statistics are used to determine the internal consistency of the instrument, resulting in reliability co-efficient of 0.83 . Mean and standard deviation are used to answer research questions while statistical ANOVA was used to test the hypothesis. The study found that 25 competency skills, competencies 18 businesses, and 19 competency attitudes required by graduates in computer education for sustainable jobs in programming. These competencies are identified, among others, the ability to compose a program code, test and debug quickly and efficiently; explore and evaluate the design of the application, analyze the needs and specifications and then design, test, develop software to meet those needs, recommend upgrading the software to the user's client programs and systems, proficiency in data mining, confidence but open to feedbacks, adapting to changes while remaining focused on project with topmost priority and good sense of judgment. It was therefore recommended that the identified competencies should be incorporated in the curriculum for training Computer Education graduates for sustainability in programming jobs.
\end{abstract}

Keywords : computer programmer, sustainability, job, competence, graduate

This is an open access article distributed under the Creative Commons 4.0 Attribution License 


\section{Pendahuluan}

Pemrograman komputer sangat diperlukan dalam era teknologi. Pemrograman komputer, sebagai suatu program studi, adalah studi tentang konsep-konsep dasar pemrograman termasuk algoritma dan alat-alat algoritmik, jenis kesalahan, debugging, struktur data, bahasa pemrograman komputer yang berbeda (tingkat rendah dan tingkat tinggi) dan sejenisnya. Sebagai sebuah seni, pemrograman komputer melibatkan kemampuan menulis, pemeliharaan dan extensible source code yang dapat diterjemahkan oleh program penerjemah untuk melakukan tugas yang bermakna. Pemrograman komputer membantu seseorang memahami komputer, atau lebih tepatnya, memperoleh lebih banyak pengetahuan tentang bagaimana komputer bekerja. Menurut [1], pemrograman komputer memungkinkan pengguna komputer untuk berinteraksi dengan mesin terkomputerisasi dan komputer, memanfaatkan kekuatan komputasi dalam semua usaha manusia, mengotomatisasi tugas dan menciptakan mesin cerdas. Berdasarkan definisi tersebut, pemrograman komputer adalah seni menulis source code yang dapat berjalan di berbagai platform termasuk sistem operasi, internet, smartphone, perangkat komputer dibantu, atau kombinasi dari peralatan komputer. Pemrograman komputer adalah salah satu program inti yang dipelajari oleh mahasiswa pendidikan komputer, yang memungkinkan mereka mampu bersaing dengan orang lain dalam industri TI. Lulusan pendidikan komputer adalah individu yang dilatih pada teori, praktek dan paradigma filosofis profesi (pendidikan komputer). Lulusan pendidikan komputer dilatih untuk menduduki posisi mengajar dan kepemimpinan di sekolah menengah, sekolah teknik, Pendidikan Sekolah Tinggi, universitas, dan program pelatihan di perusahaan Institut inovatif. Mereka juga dilatih untuk menjadi wiraswasta atau bekerja di perusahaan-perusahaan pengembangan perangkat lunak, industri, dan antar sesama programmer, perusahaan pemeliharaan perangkat keras lainnya, Teknologi Informasi (TI) perusahaan. Lulusan pendidikan komputer perlu upaya untuk memahami implikasi dari trend terbaru dalam bahasa pemrograman. Pada tingkat yang lebih mendasar dan kemampuan diri, menurut [1], lulusan pendidikan komputer perlu memahami bahwa mata kuliah keterampilan pemrograman, dan tingkat kompetensi, akan menjadi penentu yang signifikan dari keberhasilan sepanjang karier mereka. Implikasi dari ini menurut penulis adalah untuk menanamkan pada mahasiswa pendidikan komputer di tahap awal, tingkat lanjut diperlukannya keterampilan pemrograman yang berguna; untuk menyiapkan mahasiswa dengan kompetensi (keterampilan, pengetahuan dan sikap) yang diperlukan untuk belajar dan tahu bagaimana meningkatkan pembelajaran sehingga mereka dapat tetap up-to-date secara lebih efisien dan efektif. Selain itu, perlu ada infrastruktur untuk mendukung lulusan pendidikan komputer untuk mendukung kemajuan melalui karir mereka.

Kompetensi adalah pola terukur pengetahuan, keterampilan, kemampuan, perilaku, dan karakteristik lain bahwa kebutuhan individu untuk melakukan peran dalam pekerjaan [3]. Kompetensi menggambarkan tindakan yang terletak di belakang kinerja yang sukses. Hal ini memungkinkan instruktur untuk mendukung bahwa pelajar telah belajar apa yang dimaksudkan dalam pengalaman tujuan belajar atau belajar. Deskripsi kompetensi menunjukkan seorang karyawan dengan tingkat pengetahuan dan penguasaan keterampilan yang diperlukan untuk berhasil melakukan tugas pekerjaan, dan standar perilaku harus secara konsisten ditunjukkan. Lulusan pendidikan komputer dapat menggunakan kompetensi untuk merencanakan jalur karir. Mengetahui kompetensi sangat penting untuk mendapatkan dan mempertahankan pekerjaan serta promosi tertentu. Dengan demikian, memungkinkan lulusan pendidikan komputer mencari dan membuka kesempatan pelatihan kurikulum dan pengembangan ekstra yang relevan. Akuisisi kompetensi yang sesuai mampu menempatkan individu pada pekerjaan secara tepat, meningkatkan kinerja seseorang dan kenyamanan dalam bekerja, dipromosikan, dan mempertahankan sebuah pekerjaan. Kerja berkelanjutan adalah cara membangun ketahanan untuk mengatasi goncangan di masa depan dan memungkinkan transisi di masa depan dan kemajuan di tempat kerja. Level pekerjaan menunjukkan seberapa relevan pekerja dengan pekerjaannya. Kemampuan untuk mempertahankan pekerjaan tergantung pada gaji dan kualitas kompetensi yang dimiliki oleh karyawan. Kerja yang berkelanjutan tergantung pada kemampuan karyawan dalam memelihara keterampilan, bisnis dan kompetensi sikap yang diperlukan. Dalam konteks penelitian ini, pekerjaan yang berkelanjutan adalah kemampuan dari pekerjaan dapat dipertahankan untuk waktu yang tidak terbatas.

Pemrograman komputer adalah salah satu keterampilan yang menguntungkan dan diperlu- 
kan di era IT ini. Pasar kerja untuk programmer sudah tersedia secara luas. Pertumbuhan programmer komputer mengindikasikan kekurangan bahwa tersedia lebih banyak pekerjaan yang memerlukan keterampilan dari orang-orang yang memiliki keterampilan pemrograman. Hal ini dapat dikaitkan dengan perbedaan antara apa yang diajarkan di universitas dan praktek pemrograman yang sebenarnya yang dihadapi lulusan pendidikan komputer.

Tampaknya ada ketidaksesuaian antara permintaan pasar untuk lulusan pendidikan komputer dengan kompetensi pemrograman yang diperlukan dan isi kurikulum pemrograman pada pendidikan komputer di tingkat tersier pendidikan di Indonesia. Oleh karena itu, ada kesenjangan antara kompetensi lulusan pemrograman pada pendidikan komputer di sekolah tinggi dan apa yang diharapkan dunia IT. Hal ini mungkin karena dosen pendidikan komputer tidak memiliki kompetensi pemrograman yang diperlukan untuk memecahkan masalah pemrograman komputer saat ini, kekurangan kompetensi yang ditetapkan dan ketidakmampuan universitas untuk mendapatkan pemrograman kompetensi terbaru yang diharapkan lulusan pendidikan komputer. Dampaknya adalah terjadi peningkatan pengangguran, bekerja pada bidang yang tidak relevan di industri TI dan penurunan keterampilan bertahap pada lulusan pendidikan komputer sebagai akibat dari munculnya bahasa pemrograman baru dan teknologi. Isu-isu jelek menimbulkan keraguan pada kompetensi pemrograman diajarkan kepada mahasiswa di universitas. Hal ini berlawanan dengan latar belakang penelitian ini, bahwa peneliti berusaha untuk memastikan kompetensi yang dibutuhkan oleh lulusan pendidikan komputer pada pemrograman komputer untuk pekerjaan berkelanjutan di Kota Pekanbaru Provinsi Riau. Secara khusus, penelitian ini berusaha untuk memastikan:

1) kompetensi keterampilan yang dibutuhkan oleh lulusan pendidikan komputer pada pemrograman komputer untuk pekerjaan berkelanjutan;

2) kompetensi sikap yang dibutuhkan oleh lulusan pendidikan komputer pada pemrograman komputer untuk pekerjaan berkelanjutan;

3) kompetensi Bisnis dibutuhkan oleh lulusan pendidikan komputer pada pemrograman komputer untuk pekerjaan berkelanjutan.

Dosen komputer, instruktur pemrograman dan programmer tidak berbeda secara signifikan dalam pendapat mereka tentang kompetensi yang dibutuhkan oleh lulusan komputer pada pemrograman komputer untuk pekerjaan berkelanjutan di
Kota Pekanbaru Provinsi Riau.

\section{METODA}

Studi ini mengadopsi desain penelitian survei deskriptif dengan tujuan untuk mengeksplorasi pendapat responden pada pengarsipan digital. Hal ini sejalan dengan pandangan [4] bahwa survei deskriptif berfokus pada keyakinan, pendapat, sikap, motivasi dan perilaku masyarakat. Penulis menyatakan bahwa melalui survei, peneliti mengidentifikasi kondisi saat ini, kebutuhan yang berlaku serta memberikan informasi yang keputusan dasar. Penelitian dilakukan di Kota Pekanbaru Provinsi Riau, Indonesia, dengan fokus pada perguruan tinggi, Institusi Inovatif Kewirausahaan dan IT perusahaan. Populasi untuk penelitian ini terdiri dari sembilan puluh lima responden. Ini terdiri dari 74 dosen, 6 instruktur pemrograman dan 15 programmer.

Kuesioner terstruktur digunakan untuk memperoleh informasi dari responden. Instrumen berisi dua bagian. Bagian I berurusan dengan karakteristik demografi responden. Bagian II terkandung 63 item kompetensi terdiri dari 25, 19 dan 19 item dalam tiga kelompok $\mathrm{A}, \mathrm{B}$ dan $\mathrm{C}$ masing-masing. Instrumen menjadi sasaran validasi oleh tiga ahli, salah satu dari universitas dan masing-masing dari IT Inovatif Enterprise Institute dan sebuah perusahaan IT. Pilihan respon empat; Sangat Diperlukan (SD), Diperlukan (D), Kurang Diperlukan (KD) dan Tidak Diperlukan (TD) serta Sangat Tidak Diperlukan (STD) yang digunakan dalam instrumen. Cronbach Alpha digunakan untuk menentukan konsistensi internal dari item dalam instrumen dan reliabilitas koefisien 0,83 diperoleh menunjukkan konsistensi tinggi. Data yang dikumpulkan dianalisis dengan menggunakan mean dan deviasi standar untuk menjawab pertanyaan penelitian sementara statistik ANOVA digunakan untuk menguji hipotesis nol pada 0,05 tingkat signifikan. Setiap item dengan nilai rata-rata 2,50 dan di atas mengindikasikan bahwa kompetensi sangat diperlukan. Di sisi lain, setiap item yang nilainya rata-rata di bawah 2,50 menunjukkan bahwa item kompetensi tidak diperlukan. Dalam pengujian hipotesis, dimana nilai signifikansi F-dihitung lebih besar dari tingkat signifikansi $(0,05)$ di mana hipotesis diuji, maka, tidak ada perbedaan signifikan yang ada dalam tanggapan responden dan hipotesis itu ditegakkan, jika tidak, itu tidak ditegakkan. 


\section{HASIL DAN PEMBAHASAN}

\section{A. Pertanyaan Penelitian 1}

Apa kompetensi keterampilan yang dibutuhkan oleh lulusan komputer pada pemrograman komputer untuk pekerjaan berkelanjutan? Data untuk menjawab pertanyaan penelitian 1 disajikan pada Tabel 1. Peringkat dan analisis standar deviasi tanggapan dari dosen komputasi, instruktur pemrograman dan programmer pada kompetensi teknis yang diperlukan oleh lulusan komputer pada pemrograman komputer untuk pekerjaan berkelanjutan.

Tabel 1. Data Jawaban Pertanyaan Peneliti 1

\begin{tabular}{|c|c|c|c|}
\hline $\begin{array}{c}\text { Competency } \\
\text { Items Required }\end{array}$ & Mean & SD & Remark \\
\hline rq1-01 & 3.89 & 0.40 & diperlukan \\
rq1-02 & 3.37 & 0.77 & diperlukan \\
rq1-03 & 3.69 & 0.62 & diperlukan \\
rq1-04 & 3.30 & 0.70 & diperlukan \\
rq1-05 & 3.49 & 0.65 & diperlukan \\
rq1-06 & 3.28 & 0.91 & diperlukan \\
rq1-07 & 3.54 & 0.65 & diperlukan \\
rq1-08 & 3.05 & 0.78 & diperlukan \\
rq1-09 & 3.46 & 0.73 & diperlukan \\
rq1-10 & 3.19 & 0.88 & diperlukan \\
rq1-11 & 3.32 & 0.78 & diperlukan \\
rq1-12 & 3.17 & 0.85 & diperlukan \\
rq1-13 & 3.14 & 0.89 & diperlukan \\
rq1-14 & 2.92 & 0.81 & diperlukan \\
rq1-15 & 3.22 & 0.98 & diperlukan \\
rq1-16 & 3.35 & 0.75 & diperlukan \\
rq1-17 & 2.86 & 0.79 & diperlukan \\
rq1-18 & 2.92 & 0.68 & diperlukan \\
rq1-19 & 2.69 & 0.82 & diperlukan \\
rq1-20 & 2.92 & 0.80 & diperlukan \\
rq1-21 & 2.94 & 0.67 & diperlukan \\
rq1-22 & 2.86 & 0.86 & diperlukan \\
rq1-23 & 2.76 & 0.96 & diperlukan \\
rq1-24 & 3.22 & 0.98 & diperlukan \\
rq1-25 & 3.54 & 0.65 & diperlukan \\
\hline Cluster Values & 3.20 & 0.77 & diperlukan \\
\hline
\end{tabular}

Hasil yang disajikan pada Tabel 1 menunjukkan bahwa semua dari 25 item kompetensi keterampilan yang diperlukan oleh lulusan komputer untuk pekerjaan berkelanjutan di industri TI dengan penilaian mean dan deviasi standar antara 2,69-3,89 dan 0,40-0,98 masingmasing. Rerata akhir 3.20 menunjukkan bahwa, secara umum, kompetensi keterampilan sangat dibutuhkan oleh lulusan komputer pada pemrograman komputer untuk pekerjaan berkelanjutan. Standar deviasi dari 0,77 menunjukkan bahwa pendapat dosen komputasi, instruktur pemrograman dan programmer pada kompetensi keterampilan yang dibutuhkan oleh lulusan komputer pada pemrograman komputer, yang hampir sama. Perbandingan antara item dalam kompetensi kemampuan pemrograman di tampilkan pada gambar 1 .

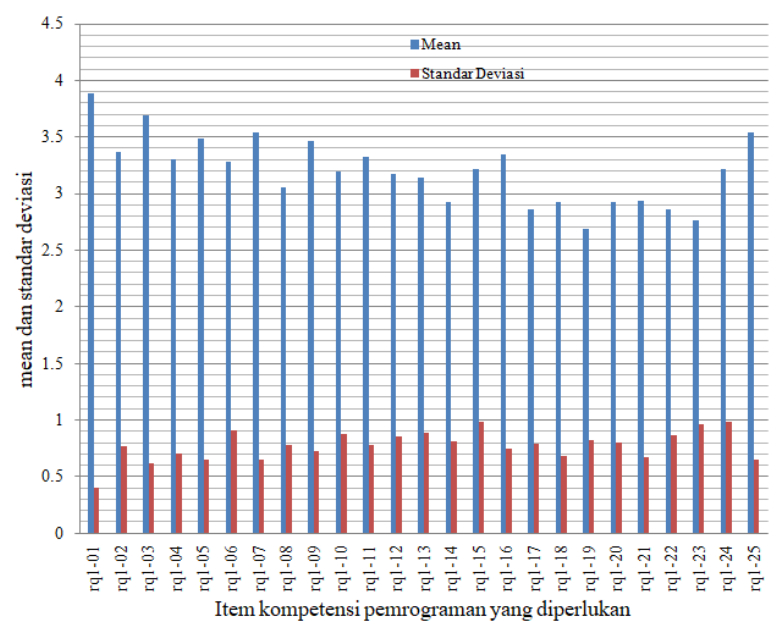

Gambar 1. Kompetensi Pemrograman

\section{B. Pertanyaan Penelitian 2}

Apa kompetensi bisnis yang dibutuhkan oleh lulusan komputer pada pemrograman komputer untuk pekerjaan berkelanjutan; Data untuk menjawab pertanyaan penelitian 2 disajikan pada Tabel 2. Peringkat dan standar deviasi dari respon dosen komputasi, instruktur pemrograman dan programmer pada kompetensi bisnis yang dibutuhkan oleh lulusan komputer pada pemrograman komputer untuk pekerjaan berkelanjutan

Tabel 2. Data Jawaban Pertanyaan Peneliti 2

\begin{tabular}{|c|c|c|c|}
\hline $\begin{array}{c}\text { Competency } \\
\text { Items Required }\end{array}$ & Mean & SD & Remark \\
\hline rq2-01 & 3.49 & 0.73 & diperlukan \\
rq2-02 & 3.27 & 0.84 & diperlukan \\
rq2-03 & 3.35 & 0.79 & diperlukan \\
rq2-04 & 3.58 & 0.77 & diperlukan \\
rq2-05 & 3.39 & 0.77 & diperlukan \\
rq2-06 & 3.00 & 0.91 & diperlukan \\
rq2-07 & 2.08 & 0.89 & diperlukan \\
rq2-08 & 2.91 & 0.87 & diperlukan \\
rq2-09 & 3.00 & 0.75 & diperlukan \\
rq2-10 & 2.57 & 0.70 & diperlukan \\
rq2-11 & 3.22 & 0.85 & diperlukan \\
rq2-12 & 3.16 & 0.76 & diperlukan \\
rq2-13 & 3.11 & 0.84 & diperlukan \\
rq2-14 & 3.05 & 0.78 & diperlukan \\
rq2-15 & 3.22 & 0.85 & diperlukan \\
rq2-16 & 3.22 & 0.85 & diperlukan \\
rq2-17 & 2.57 & 0.70 & diperlukan \\
rq2-18 & 2.57 & 0.70 & diperlukan \\
rq2-19 & 3.00 & 0.91 & diperlukan \\
\hline Cluster Values & 3.03 & 0.80 & diperlukan \\
\hline
\end{tabular}

Data yang disajikan dalam Tabel 2 menggambarkan bahwa 18 dari item kompetensi 19 bisnis yang diperlukan oleh lulusan komputer 
untuk pekerjaan berkelanjutan di industri TI dengan penilaian mean dan deviasi standar antara 2,57-3,49 dan 0,70-0,91 masing-masing. Namun, rerata 3,03 menunjukkan bahwa, secara umum, kompetensi bisnis yang sangat dibutuhkan oleh lulusan komputer pada pemrograman komputer untuk pekerjaan berkelanjutan. Standar deviasi dari 0,80 menunjukkan bahwa pendapat dosen komputasi, instruktur pemrograman dan programmer pada kompetensi bisnis yang dibutuhkan oleh lulusan komputer pada pemrograman komputer, sangat dekat satu sama lain. Gambar 1 menunjukkan perbandingan antara satu item dengan item yang lain dalam kompetensi kemampuan bisnis

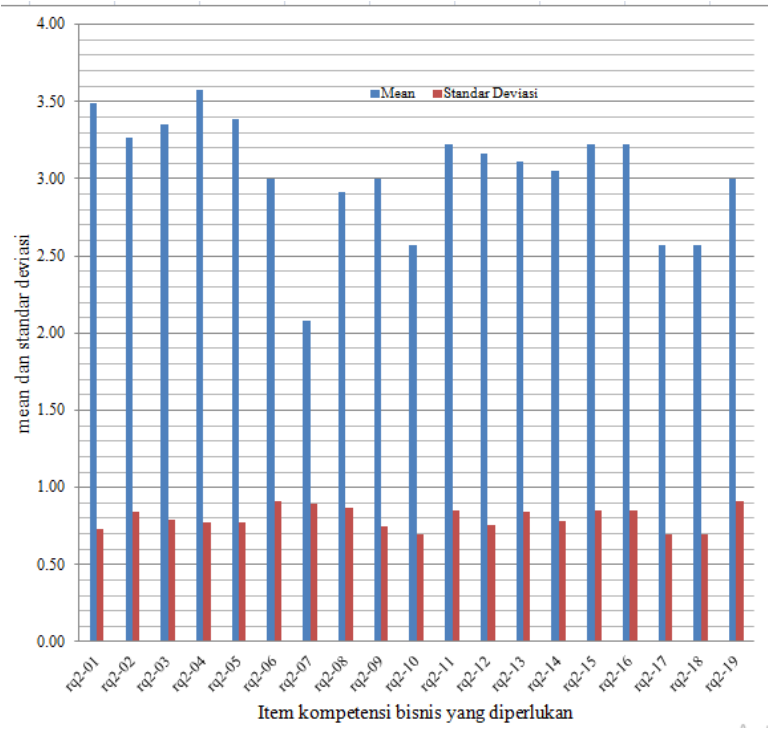

Gambar 2. Kompetensi Bisnis yang Diperlukan

\section{Pertanyaan Penelitian 3}

Apa kompetensi sikap yang dibutuhkan oleh lulusan komputer pada pemrograman komputer untuk pekerjaan berkelanjutan; Data untuk menjawab pertanyaan penelitian 3 disajikan pada tabel 3 di bawah ini. Peringkat dan standar deviasi dari respon dosen komputasi, instruktur pemrograman dan programmer pada kompetensi sikap yang dibutuhkan oleh lulusan komputer pada pemrograman komputer untuk pekerjaan berkelanjutan.

Hasil yang disajikan pada Tabel 3 menunjukkan bahwa semua 19 item kompetensi sikap yang diperlukan oleh lulusan komputer untuk pekerjaan berkelanjutan di industri TI dengan penilaian mean dan deviasi standar antara 2,84-3,51 dan 0,69-0,96 masing-masing. Rerata 3.20 menunjukkan bahwa, secara umum, kompetensi teknis yang sangat dibutuhkan oleh lulusan komputer pada pemrograman komputer untuk pekerjaan ber- kelanjutan. Standar deviasi dari 0,78 menunjukkan bahwa pendapat dosen komputer, instruktur pemrograman dan programmer pada kompetensi keterampilan yang dibutuhkan oleh lulusan komputer pada pemrograman komputer, sangat dekat satu sama lain. Gambar 3 menyajikan perbandingan item yang diperlukan dalam kompetensi sikap.

Tabel 3. Data Jawaban Pertanyaan 3

\begin{tabular}{|c|c|c|c|}
\hline $\begin{array}{c}\text { Competency } \\
\text { Items Required }\end{array}$ & Mean & SD & Remark \\
\hline rq3-01 & 3.27 & 0.84 & diperlukan \\
rq3-02 & 3.11 & 0.70 & diperlukan \\
rq3-03 & 3.14 & 0.80 & diperlukan \\
\hline rq3-04 & 3.35 & 0.73 & diperlukan \\
rq3-05 & 3.49 & 0.73 & diperlukan \\
rq3-06 & 3.41 & 0.80 & diperlukan \\
rq3-07 & 3.51 & 0.69 & diperlukan \\
rq3-08 & 3.35 & 0.82 & diperlukan \\
rq3-09 & 2.84 & 0.96 & diperlukan \\
rq3-10 & 2.84 & 0.96 & diperlukan \\
rq3-11 & 3.27 & 0.80 & diperlukan \\
rq3-12 & 3.46 & 0.69 & diperlukan \\
rq3-13 & 3.00 & 0.88 & diperlukan \\
rq3-14 & 3.11 & 0.84 & diperlukan \\
rq3-15 & 3.00 & 0.88 & diperlukan \\
rq3-16 & 3.46 & 0.69 & diperlukan \\
rq3-17 & 3.46 & 0.69 & diperlukan \\
rq3-18 & 3.27 & 0.80 & diperlukan \\
rq3-19 & 3.51 & 0.69 & diperlukan \\
\hline Cluster Values & 3.28 & 0.78 & diperlukan \\
\hline
\end{tabular}

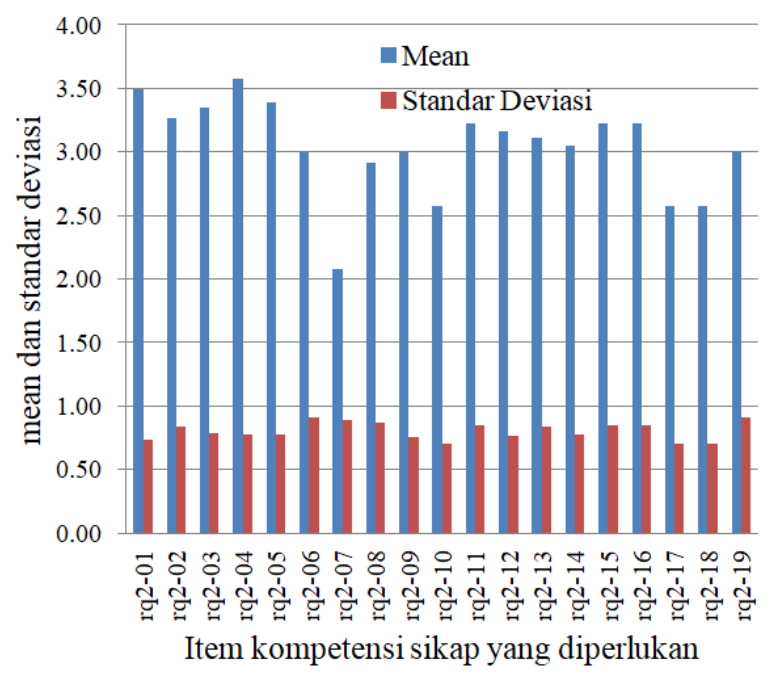

Gambar 3. Kompetensi Sikap yang Diperlukan

Tabel 4 memaparkan data ringkasan analisis ANOVA tanggapan dari dosen komputasi, instruktur pemrograman dan programmer pada kompetensi keterampilan yang dibutuhkan oleh lulusan komputer pada pemrograman komputer untuk pekerjaan berkelanjutan 
Tabel 4. Cluster 1: Hard Competencies

\begin{tabular}{|c|c|c|c|c|c|c|}
\hline Desc. & SS & $\mathrm{df}$ & MS & $\mathrm{F}$ & Sig & $\mathrm{R}$ \\
\hline anta & 0.062 & 2 & 0.031 & & & \\
\hline dalam & 2.134 & 22 & 0.097 & 0.321 & 0.728 & $\begin{array}{l}\mathrm{N} \\
\mathrm{S}\end{array}$ \\
\hline total & 2.197 & 24 & & & & \\
\hline
\end{tabular}

Hasil pada Tabel 4 menunjukkan tiga kelompok dengan nilai-F 0,321 dan nilai-Sig 0,728 yang lebih besar dari tingkat signifikansi 0,05 , menunjukkan bahwa hipotesis nol adalah benar. Oleh karena itu, kesimpulan yang ditarik adalah bahwa dosen komputasi, instruktur pemrograman dan programmer tidak berbeda secara signifikan dalam pendapat mereka tentang kompetensi keterampilan yang dibutuhkan oleh lulusan komputer pada pemrograman komputer untuk pekerjaan berkelanjutan di Kota Pekanbaru Provinsi Riau, Indonesia. Tabel 5 memaparkan ringkasan analisis ANOVA tanggapan dari dosen komputasi, instruktur pemrograman dan programmer pada kompetensi bisnis yang dibutuhkan oleh lulusan komputer pada pemrograman komputer untuk pekerjaan berkelanjutan

Tabel 5. Cluster 2: Soft Competencies

\begin{tabular}{|c|c|c|c|c|c|c|}
\hline Desc. & SS & $\mathrm{df}$ & MS & $\mathrm{F}$ & Sig & $\mathrm{R}$ \\
\hline $\begin{array}{l}\text { antara } \\
\text { group }\end{array}$ & 0.568 & 2 & 0.293 & & & \\
\hline $\begin{array}{l}\text { dalam } \\
\text { group }\end{array}$ & 2.352 & 16 & 0.147 & 1.995 & 0.176 & $\begin{array}{l}\mathrm{N} \\
\mathrm{S}\end{array}$ \\
\hline total & 2.938 & 18 & & & & \\
\hline
\end{tabular}

Hasil pada Tabel 6 menunjukkan tiga kelompok dengan nilai-F 0,079 dan nilai-Sig 0,782 yang lebih besar dari tingkat signifikansi 0,05 , menunjukkan bahwa hipotesis nol adalah diterima. Oleh karena itu, tidak ada perbedaan yang ada signifikan dalam peringkat rata-rata tanggapan dari dosen komputasi, instruktur pemrograman dan programmer pada kompetensi sikap yang dibutuhkan oleh lulusan komputer pada pemrograman komputer untuk pekerjaan berkelanjutan di Kota Pekanbaru Provinsi Riau, Indonesia

Tabel 6. Cluster 3: Soft Competencies

\begin{tabular}{|c|c|c|c|c|c|c|}
\hline Desc. & SS & $\mathrm{df}$ & MS & $\mathrm{F}$ & $\mathrm{Sig}$ & $\mathrm{R}$ \\
\hline antara & 0.006 & 2 & 0.003 & & & \\
\hline dalam & 0.656 & 16 & 0.041 & 0.079 & 0.782 & $\begin{array}{l}\mathrm{N} \\
\mathrm{S}\end{array}$ \\
\hline total & 0.662 & 18 & & & & \\
\hline
\end{tabular}

Hasil pada Tabel 6 menunjukkan tiga kelompok dengan nilai-F 0,079 dan nilai-Sig 0,782 yang lebih besar dari tingkat signifikansi 0,05 , menunjukkan bahwa hipotesis nol diterima. Oleh karena itu, tidak ada perbedaan yang ada signifikan dalam peringkat rata-rata tanggapan dari dosen komputasi, instruktur pemrograman dan programmer pada kompetensi sikap yang dibutuhkan oleh lulusan komputer pada pemrograman komputer untuk pekerjaan berkelanjutan di Kota Pekanbaru, Provinsi Riau.

Hasil penelitian ini mengungkapkan bahwa kompetensi keterampilan, kompetensi bisnis dan kompetensi sikap yang sangat dibutuhkan oleh lulusan komputer pada pemrograman komputer untuk pekerjaan berkelanjutan. Ini berarti bahwa untuk lulusan komputer di Provinsi Riau untuk mendapatkan dan mempertahankan pekerjaan di pemrograman komputer, mereka perlu untuk secara efektif meningkatkan kompetensi keterampilan, profesional dan sikap. Temuan ini menguatkan dengan studi [5] yang menunjukkan bahwa campuran heterogen keterampilan yang dibutuhkan oleh pemrogram komputer. Temuan ini juga sejalan dengan pendapat [6] yang percaya bahwa hard skill yang baik dilengkapi dengan soft skill yang baik diperlukan oleh programmer. Temuan ini juga sesuai dengan laporan dari [7], [8] dan [9] bahwa kebutuhan programmer komputer membutuhkan kombinasi beberapa skill.

Temuan ini mengungkapkan bahwa 25 item kompetensi keterampilan yang diperlukan oleh lulusan komputer pada pemrograman komputer untuk pekerjaan berkelanjutan. Hasil hipotesis menunjukkan tiga kelompok dengan nilai-F 0,321 dan nilai-Sig 0,728 yang lebih besar dari tingkat signifikansi 0,05 . Karena nilai-Sig $>0,05$ tingkat signifikansi, hipotesis nol diterima.

Oleh karena itu, disimpulkan bahwa dosen komputasi, instruktur pemrograman dan programmer tidak berbeda secara signifikan dalam pendapat mereka tentang kompetensi keterampilan yang dibutuhkan oleh lulusan komputer pada pemrograman komputer untuk pekerjaan berkelanjutan di Kota Pekanbaru. Hal ini menunjukkan merujuk pada laporan dari [10] bahwa kemampuan untuk menggunakan platform mobile, proses pengembangan perangkat cerdas dan toolset, bagaimana melakukan estimasi efektif, Java Script, server side script, Structured Query language (SQL) dan Hyper Text Mark-up language (HTML). Merupakan beberapa kompetensi keterampilan yang diperlukan oleh programmer. Merujuk pada laporan [11], yang menekankan kemahiran dalam bahasa asing, gelar 
atau sertifikat, kemampuan untuk menggunakan beragam jenis alat, bisa membangun model matematika dari proses yang mendasari, kemampuan untuk turut dalam Software Open Source (OSS). Uraian tersebut sebagai kompetensi keterampilan programmer harus dimiliki.

Temuan ini mengungkapkan bahwa 18 bisnis kompetensi item yang diperlukan oleh lulusan pemrograman komputer untuk pekerjaan berkelanjutan. Hasil hipotesis menunjukkan tiga kelompok dengan nilai-F 1,995 dan nilai-Sig 0,176 yang lebih besar dari tingkat signifikansi 0,05 . Karena nilai-Sig $>0,05$ tingkat signifikansi, hipotesis nol tidak ditolak. Oleh karena itu, kesimpulan yang ditarik adalah bahwa peringkat rerata pendapat dosen komputasi, instruktur pemrogra-man dan programmer pada kompetensi bisnis yang dibutuhkan oleh lulusan komputer pada pemrograman komputer untuk pekerjaan berkelanjutan di Kota Pekanbaru Provinsi Riau secara signifikan yang sama.

Temuan ini mengungkapkan bahwa 19 item kompetensi sikap yang diperlukan oleh lulusan komputer pada pemrograman komputer untuk pekerjaan berkelanjutan. Hasil hipotesis menunjukkan tiga kelompok dengan nilai-F 0,079 dan nilai-Sig 0,782 yang lebih besar dari tingkat signifikansi 0,05. Karena nilai-Sig $>0,05$ tingkat signifikansi, hipotesis nol diterima. Oleh karena itu, kesimpulan bahwa perbedaan yang signifikan tidak ada pada rerata tanggapan dari dosen komputasi, instruktur pemrograman dan programmer pada kompetensi sikap yang dibutuhkan oleh lulusan komputer pada pemrograman komputer untuk pekerjaan berkelanjutan di Kota Pekanbaru Provinsi Riau. Temuan ini senada dengan pandangan [12], [13], [14] dan [15] yang menemukan kemampuan untuk membuat atau memulai ide, delegasi yang efektif, kemampuan untuk memberikan mentoring dan dukungan kepada client, kemampuan untuk memenuhi tenggat waktu, memperhatikan detail, memiliki ingatan yang baik, negosiasi kontrak, kemampuan untuk berpikir secara abstrak, dan pada beberapa tingkatan; dan berbagai atribut lainnya sebagai kompetensi sikap yang penting untuk sukses karir dalam pemrograman komputer.

\section{KESIMPULAN}

Disimpulkan dari penelitian ini, lulusan komputer memerlukan kompetensi gabungan keterampilan, bisnis dan kompetensi sikap. Kompetensi ini akan memberdayakan lulusan untuk memulai pengembangan perangkat lunak, memperoleh dan mempertahankan pekerjaan di bidang pemrograman komputer. Selain itu, akuisisi kompetensi ini dengan lulusan komputer akan membantu meningkatkan ketersediaan programmer di Kota Pekanbaru Provinsi Riau, Indonesia. Berdasarkan temuan penelitian ini, pengajaran dari berbagai konsep dasar bermuara pada keterampilan, bisnis dan kompetensi sikap yang dibutuhkan oleh lulusan komputer pada pemrograman komputer harus diajarkan secara intensif untuk memastikan kemampuan yang cukup dari lulusan komputer. Peralatan yang relevan dan bahan ajar lainnya harus memadai disediakan untuk kursus pemrograman komputer sehingga memungkinkan dosen komputer dan instruktur pemrograman IT memanfaatkan dalam mengajar secara efektif. Juga, lulusan komputer harus cukup peka untuk mengembangkan diri secara sadar untuk kemampuan pemrograman yang diperlukan dalam kompetensi yang berhubungan dengan pekerjaan sebelum dan setelah lulus, untuk memungkinkan mereka memperoleh dan mempertahankan pekerjaan kelak. Kompetensi yang diidentifikasi dalam studi harus dimasukkan dalam program pelatihan komputer di semua perguruan tinggi sehingga dapat digunakan untuk pengajaran, pelatihan dan pelatihan ulang programmer. Kompetensi yang telah diidentifikasi harus dibuat tersedia untuk semua mahasiswa komputer oleh pemerintah melalui media untuk memungkinkan mereka memperoleh kompetensi yang diperlukan untuk pekerjaan berkelanjutan di industri TI. Kemudian, kompetensi yang telah diidentifikasi juga harus dimasukkan ke dalam ilmu komputer, teknologi komputer dan kurikulum pendidikan komputer untuk perguruan tinggi di Indonesia sehingga mahasiswa komputer akan memperoleh kompetensi sebelum lulus. Terakhir, lulusan pendidikan komputer harus tetap up-to-date dengan kecepatan di mana perubahan teknologi; karena setiap pengguna IT mencari karyawan dengan syarat kompetensi pemrograman yang unggul.

\section{DAfTAR PUStaka}

[1] Holden, John. (2017). Coding will be the most important skill in the future, Thu, Nov 26, 2019, 06:15,

from https://www.irishtimes.com/profile/john-holden7.1837474

[2] A. McGettrick, R. Boyle, R. Ibbett, J. Lloyd, G. Lovegrove and K. Mander, "Grand Challenges in Computing: Education-A Summary," in The 
Computer Journal, vol. 48, no. 1, pp. 42-48, Jan. 2005. doi: 10.1093/comjnl/bxh064

[3] Beckett, Sarah. (2018). What's The Difference Between Skills and Competencies? Retrieved Thu, Nov 26, 2019, 06:15, from https://resources.hrsg.ca/blog/what-s-thedifference-between-skills-and-competencies

[4] Bailey, Janet., Mitchell, Robert B. (2006). Industry Perceptions of the Competencies Needed by Computer Programmers: Technical, Business, and Soft Skills, Journal of Computer Information Systems, 47:2, 28-33, DOI: 10.1080/08874417.2007.11645951

[5] Sharma, B. (2008). What kind of skills does a Java developer need (Jobs Discussion forum at JavaRanch) html. Retrieved November 20, 2019, from

http://www.coderanch.com/t/33318/Jobs/careers/k ind-skills-Java-developer

[6] Al Shamsi, Fatima., Elnagar, Ashraf., An Intelligent Assessment Tool for Students' Java Submissions in Introductory Programming Courses, Journal of Intelligent Learning Systems and Applications, 2012, 4, 59-69 ttp://dx.doi.org/10.4236/jilsa.2012.41006

Published Online February 2012 (http://www.SciRP.org/journal/jilsa).

[7] Tucker, D. (2014). 10 Skills Developers Should Invest In for 2014. Retrieved September 12, 2015, from https://medium.com/universal-mind/10skills-developers-should-invest-in-for-201464eb28781489

[8] Chawla, Deepak., Dokadia, Afsha., Rai, Snigdha. (2017). Multigenerational Differences in Career Preferences, Reward Preferences and Work Engagement among Indian Employees. Volume: 18 issue: 1, page(s): 181-197. https://doi.org/10.1177/0972150916666964

[9] Weisfeld, M. (2013). What Skills Employers Want in a Software Developer: My Conversations with Companies Who Hire Programmers. Retrieved December 5, 2019, from http://www.informit.com/articles/article.aspx?p=2 156240
[10] Chilana, P. K., Singh, R., \& Guo, P. J. (2016). Understanding conversational programmers: A perspective from the software industry. Conference on Human Factors in Computing Systems - Proceedings, 1462-1472. https://doi.org/10.1145/2858036.2858323

[11] Strom, D. (2014). The 10 Most Important Programming Skills Your Business Needs to Employ. Retrieved December 20, 2019, from https://www.workintelligent.ly/technology/trends/ 2014-4-17-programming-skills-business-needs/

[12] Erstad, W. (2014). 5 Soft Skills Every Programmer Needs (And You Might Already Have!). Retrieved December 17, 2019, from http://www.rasmussen.edu/degrees/technology/bl og/5-soft-skills-programmers-ne

[13]Han, L. (2014). Soft Skills Definition: What are Soft Skills? Retrieved December 6, 2015, from https://bemycareercoach.com/soft-skills/what-aresoft-skills

[14] Shacklett, M. (2013). 10 highly valued soft skills for IT pros. Retrieved November 26, 2019, from http://www.techrepublic.com/blog/10-things/10highly-valued-soft-skills-for-it-pros/

[15]Doyle, A. (2015). Hard Skills vs. Soft Skills. Retrieved November 28, 2019, from http://jobsearch.about.com/od/skills/qt/hard-softskills.htm

\section{Biodata Penulis}

Torkis Nasution, Lahir di Sungai Korang, 15 Desember 1972. Sarjana Teknik Informatika diperoleh dari STMIK Riau tahun 2002. Tahun 2007 memperoleh gelar Magister Teknologi Informasi di jurusan Teknologi Informasi Program Pascasarjana UPI YPTK Padang dengan bidang konsentrasi Image Processing. Staf pengajar di jurusan Teknik Informatika STMIK Amik Riau sejak tahun 2003- sekarang. 